\title{
ANALISIS EFISIENSI TEKNIS USAHATANI PADI LAHAN IRIGASI DI KABUPATEN LOMBOK BARAT
}

\author{
Hernawati \\ Program Studi Ilmu Ekonomi Pertanian, Institut Pertanian Bogor (IPB) \\ E-mail: ernawati68459@gmail.com
}

\section{RINGKASAN}

Efisiensi merupakan suatu ukuran relatif dan abstrak.; Secara individual seorang produsen hanya akan menyadari hakekat efisiensi jika inefisiensi berlangsungnya dalam waktu yang cukup lama akan merugikan karena secara sosial terjadi pemborosan sumberdaya yang semakin langka seiring dengan meningkatnya kebutuhan dan adanya proses degradasi. Penelitian ini bertujuan untuk mengetahui tingkat efisiensi teknis pada penggunaan faktor produksi pada usahatani padi di lahan irigasi di Kabupaten Lombok Barat. Rata-rata tingkat efisiensi teknis dan rata-rata produktivitas yang dicapai petani dalam usahatani padi sebesar $80 \%$ dengan menggunakan analisis frontier yakni produktivitas maksimum yang dapat dicapai dengan sistem pengelolaan yang baik, artinya petani masih memiliki peluang sekitar 20 persen untuk mencapai tingkat efisiensi maksimal 100\%. Tingkat Efisiensi Teknis yang tinggi mencerminkan prestasi petani dalam keterampilan manajerial cukup tinggi sehingga penguasaan informasi dan pengambilan keputusan dalam mengelola faktor-faktor penting yang mempengaruhi produktivitas dapat tercapai secara maksimal. Tingkat efisiensi teknis yang sudah dicapai petani dalam menggunakan faketor-faktor produksi sudah pada level yang memuaskan, namun mengingat jumlah penduduk setiap tahunnya terus bertambah yang berdampak pada peningkatan kebutuhan akan pangan khususnya beras maka untuk mempertahankan program ketahanan pangan diperlukan kebijakan pemerintah daerah untuk membuat rancangan baru khususnya tehnologi budidaya padi sehingga tingkat efisiensi yang nantinya bisa dicapai mendekati satu. Tingkat efisiensi yang tinggi juga merefleksikan bahwa peluang petani untuk meningkatkan produktivitas yang cukup tinggi semakin kecil karena perbedaan antara tingkat produktivitas yang telah dicapainya dengan tingkat produktivitas maksimum dengan sistem pengelolaan terbaik cukup kecil.

Kata Kunci: efisiensi, usahatani, padi, produksi

\section{PERNYATAAN KUNCI}

- Undang-Undang Republik Indonesia Nomor 18 Tahun 2012 Tentang
Pangan pada Bab I Ketentuan Umum

Pasal 1 ayat 4 Ketahanan Pangan adalah kondisi terpenuhinya pangan 
bagi negara sampai dengan perseorangan, yang tercermin dari tersedianya pangan yang cukup, baik jumlah maupun mutunya, aman, beragam, bergizi, merata, dan terjangkau serta tidak bertentangan dengan agama, keyakinan, dan budaya masyarakat, untuk dapat hidup sehat, aktif, dan produktif secara berkelanjutan.

- Pengendalian laju alih fungsi lahan agar luas lahan sawah irigasi atau penguasaan lahan sawah petani tidak bertambah kecil, selain itu penting untuk diupayakan peningkatan produktifitas atau kemampuan aktual tanah melalui teknologi yang ramah lingkungan.

- Rata-rata luas lahan garapan yang dikelola petani adalah 0,69 ha, dikategorikan sebagai petani Gurem yang memiliki pendapatan rendah dan hanya bisa memenuhi kebutuhan hidup keluarga mereka.

- Pengolahan lahan dengan menggunakan faktor produksi belum maksimal meskipun sudah mencapai tingkat efisiensi yang tinggi.

\section{REKOMENDASI KEBIJAKAN}

- Pemerintah daerah harus melakukan pengendalian laju alih fungsi lahan agar luas lahan sawah irigasi atau penguasaan lahan sawah petani tidak bertambah kecil.

- Pemerintah daerah harus tegas dalam impelementasikan Rencana Tata Ruang Wilayah (RTRW) yang sudah disusun.

- Pemerintah secara bersama-sama dengan swasta mendorong dan memfasilitasi penerapan teknologi SRI (System of Rice Intensification)

- Mengingat faktor yang paling berpengaruh terhadap tingkat efisiensi adalah frekuensi tanam, maka disarankan kepada pemerintah untuk menertibkan pola tanam (padipadi-palawija) khususnya pada kawasan-kawasan yang berpengairan teknis. Upaya ini perlu didukung oleh peningkatan infrastruktur jaringan irigasi dan tempat penampungan air (embung) guna mengantisipasi keadaan iklim yang sekarang ini sering merugikan petani.

- Pemerintah harus tetap melakukan peningkatan kemampuan sumber daya dan keterampilan petani melalui pendidikan dan pelatihan secara berkelanjutan dan lebih mengitensifkan peran lembaga lembaga yang dikenal petani seperti kelompok tani, gabungan kelompok tani dan lembaga penyuluhan- dengan memperhatikan metode dan inovasi baru yang cocok dengan kondisi dan 
kebutuhan petani sesuai wilayah masing masing.

\section{PENDAHULUAN}

Tanaman pangan yang sampai saat ini dianggap sebagai komoditi terpenting dan strategis bagi perekonomian Indonesia adalah padi, karena selain merupakan tanaman pokok bagi sebagian besar petani, juga merupakan bahan makanan pokok bagi penduduk Indonesia. Bangsa Indonesia telah lama mengenal tata cara bercocok tanam padi. Menurut sejarah, padi dikenal dan ditanam orang sejak Zaman Hindu atau bahkan sebelumnya. Pada umumnya masing-masing daerah mempunyai jenis jenis padi sendiri. Jenis padi itu berbeda antara satu daerah dengan yang lainnya. Perbedaannya terletak pada umur tanaman, banyaknya hasil, mutu beras dan tahan tidaknya tanaman terhadap gangguan hama dan penyakit.

Produksi padi pada tahun 2015 di Propinsi Nusa Tenggara Barat mencapai hasil sejumlah 2.417.392 ton dengan luas panen 467.503 hektar, sehingga rata-rata produksi sebesar 51,71 kw per hektar. Bila dibandingkan dengan tahun-tahun sebelumnya terlihat adanya peningkatan produksi sekitar 6,74\%. Hal ini disebabkan oleh meningkatnya luas panen sebesar 7,85\%. Tingkat produktivitasnya per hektar terlihat adanya peningkatan sebesar 1,21\%.
Peningkatan jumlah penduduk dan dibutuhkannya cadangan pangan yang setiap tahunnya semakin besar, maka sasaran produksi berikutnya harus terus diusahakan (Dinas Pertanian Tanaman Pangan Propinsi NTB, 2016).

Salah satu kabupaten yang menjadi penyumbang padi di Propinsi NTB adalah Kabupaten Lombok Barat. Tahun 2015, luas panen padi di kabupaten ini seluas 32.940 hektar dibandingkan dengan luas panen tahun sebelumnya. Peningkatan terjadi sebesar 2.094 hektar atau naik sebesar 5,17\%. Produksi padi pada tahun 2015 mencapai 171.645 ton, naik sebesar 2.457 ton atau naik sebesar 4,97\% dibanding tahun sebelumnya. Peningkatan produksi terjadi akibat adanya peningkatan luas panen yang awalnya seluas 30.846 hektar menjadi 32.940 hektar. Tingkat produktivitas per hektar terlihat adanya penurunan sebesar $\quad 0,21 \% \quad$ yaitu produktivitas tahun sebelumnya sebesar 54,17 kuintal per hektar menjadi 52,11 kw per hektar. Penurunan produktivitas ini menunjukkan para petani padi belum mampu menggunakan faktor produksi secara efisien dan maksimal (Dinas Pertanian Tanaman Pangan Propinsi NTB, 2016).

$$
\text { Mengkaji persoalan tentang }
$$
produktivitas sebenarnya mengkaji masalah efisiensi karena ukuran dari produktivitas pada hakekatnya adalah seberapa besar luaran dapat dihasilkan per unit 
masukan tertentu. Faktor harga diasumsikan given, efisiensi teknis pada akhirnya menentukan pendapatan petani (Soekartawi, 1987).

Dalam pengelolaan usahataninya, petani berhadapan dengan bagaimana mengalokasikan input secara tepat (efisien) untuk mencapai maksimasi keuntungan. Peranan input bukan hanya dapat dilihat dari segi macamnya atau ketersediaannya dalam waktu yang tepat, tetapi dapat juga dilihat dari efisiensi penggunaan faktor produksi tersebut, sehingga bagaimana petani melakukan usahatani secara efisien adalah upaya yang sangat penting. Bila petani mendapatkan keuntungan yang besar dari usahataninya, misalnya karena pengaruh harga maka petani tersebut dapat dikatakan mengalokasikan faktor produksinya secara efisiensi atau efisiensi harga (Soekartawi, 1987).

\section{SITUASI TERKINI}

Nilai efisiensi teknis bervariasi secara merata dari 66,86\% hingga 99,86\%. Ratarata tingkat efisiensi teknis yang dicapai petani dalam usahatani padi di lahan irigasi adalah 0,899 (89,9\%). Artinya, rata-rata produktivitas yang dicapai adalah sekitar $80 \%$ dari frontier yakni produktivitas maksimum yang dapat dicapai dengan sistem pengelolaan yang terbaik. Dengan demikian petani masih memiliki peluang sekitar 10,1\% untuk mencapai tingkat efisiensi maksimal 100\%.
Tingkat efisiensi seperti ini tergolong kategori tinggi dan hampir sama dengan yang dicapai petani padi di Kabupaten Lombok Tengah $(0,86)$ sebagaimana yang diperoleh dari penelitian (Rahmayani, 2008).

Hasil penelitian menunjukkan tingkat efisiensi teknis rata-rata sebesar 0,89 dengan produksi rata-rata sebesar $43,40 \mathrm{kw} / \mathrm{ha}$ atau setara dengan 42,94 kw/GKG. Angka ini telah berada diatas produktivitas rata-rata nasional sebesar 42-44 kw/GKG/ha. Akan tetapi jika dibandingkan dengan rata-rata produktivitas yang dicapai RRC (6,3 ton) adalah lebih rendah. Begitu juga jika Tingkat Efisien Teknis mencapai 1, produksi rataratanya masih dibawah RRC, yaitu 55,23 $\mathrm{kw} / \mathrm{GKG} / \mathrm{ha}$. Ini artinya bahwa produksi frontier petani responden perlu ditingkatkan minimal dapat menyamai pencapaian produktivitas RRC, misalnya dengan menggunakan teknologi baru seperti bibit hibrida varietas baru, mengembangkan teknologi budidaya padi pola SRI (system of rice intensification).

Mengacau pada karakteristik usahatani padi, upaya peningkatan efisiensi teknis kurang efektif jika dilakukan secara individual karena saling ketergantungan terutama dalam aspek pengelolaan irigasi, penanggulangan hama/penyakit tanaman dan pengalokasian tenaga kerja. Pengelolaan irigasi, interdependensi antar petani merupakan konsekuensi logis dari rancang 
bangun jaringan irigasi, teknik irigasi yang digunakan maupun status sumber daya air sebagai sumber daya publik. Penanggulangan hama dan penyakit tanaman, interdependensi antara petani merupakan implikasi logis dari karakteristik ekosistem. Demikian pula dalam penggunaan tenaga kerja, interdependensi antar pemilik dan pekerja merupakan implikasi logis dalam hubungan sosial budaya setempat.

\section{METODOLOGI}

Penelitian ini dilakukan pada tahun 2018. Metode yang digunakan adalah metode diskriptif (Nazir, 1981). Lokasi penelitian Kabupaten Lombok Barat yang tersebar pada empat kecamatan dengan jumlah sampel 100 orang responden.

\section{ANALISIS DAN ALTERNATIF SOLUSI/PENANGANAN}

Analisis yang digunakan untuk mengukur efisiensi dan tingkat produksi yang dicapai pada penggunaan input tertentu pada usahatani padi sawah lahan irigasi adalah menggunakan analisis Frontier (Coelli dan Battase, 1996). Hasil analisis menunjukkan bahwa secara keseluruhan tingkat efisiensi tinggi. Namun dalam kegiatan usahatani ditemukan terjadi pemborosan didalam pemakaian benih dan pemakaian pupuk yang tidak berimbang sehingga untuk mengatasi hal tersebut diharapkan keterlibatan dan peran aktif kelompok tani dalam kegiatan pendampingan yang dilakukan oleh pemerintah (PPL). Semua upaya yang dilakukan petani dalam rangka meningkatkan produksi dengan menambah input atau faktor produksi menghadapi fenomena ekonomi law of diminishing return (Mubyarto, 1977). Disarankan supaya petani tidak menambah secara terus menerus input tertentu akan tetapi meningkatkan jumlah dan mutu produksi diantaranya ektensifikasi, intensifikasi, spesialisasi, diversifikasi dan memberikan proteksi.

\section{REFERENSI}

Badan Pusat Statistik. 2016. Nusa Tenggara Barat dalam angka. Mataram.

Coelli, T.J., Battese, G.E. 1996. Identification of factors which influence the technical inefficiency of Indian farmers. Australian Journal of Agricultural and Resonece Economics. 40(2):103-128.

Dinas Pertanian dan Tanaman Pangan Nusa Tenggara Barat. 2016. Gema palagung. Provinsi Nusa Tenggara Barat. Mataram.

Mubyarto. 1977. Pengantar Ekonomi Pertanian. Edisi III. LP3ES. Jakarta.

Nasir, M. 1981. Metode Penelitian. Ghalia Indonesia. Jakarta.

Rahmayati. 2008. Determinasi Efisiensi Teknis Penggunaan Faktor Produksi pada Usahatani Padi Lahan Irigasi Kabupaten Lombok Barat. Mataram Press. Mataram.

Soekartawi. 1987. Prinsip Dasar Ekonomi Pertanian Teori dan Aplikasi. Rajawali Pers. Jakarta.

Undang-undang No. 18. 2012. Tanaman Pangan. Jakarta. 